İş ve İnsan Dergisi | The Journal of Human and Work

Y1l | Year: Ekim | October 2021

Cilt-Sayı | Volume-Issue: 8 (2)

ss I pp: $153-167$

doi: 10.18394/iid.954387

e-ISSN 2148-967X

http://dergipark.org.tr/iid/

Araştırma Makalesi

\title{
İçsel ve Dışsal Güdülenme Ölçeği: Geçerlilik ve Güvenilirlik Çalışması ${ }^{\mathrm{a}}$
}

\author{
Intrinsic and Extrinsic Motivation Scale: A Validity and Reliability Study
}

Fatih Çetin $^{b}$, Muhammet Ali Çelebi ${ }^{c}$

MAKALE BİLGİSI

Anahtar Kelimeler:

Güdülenme

Öz Belirleme Teorisi,

Geçerlilik ve Güvenilirlik

Tarihler :

Geliş 18 Haziran 2021

Düzeltme Geliş

24 Eylül 2021

Kabul 24 Eylül 2021

\section{ARTICLE INFO}

Keywords:

Motivation

Self Determination Theory,

Validity and Reliability

Article history:

Received 18 June 2021

Received in Revised Form

24 September 2021

Accepted

24 September 2021
ÖZ

Bu çalısmada, Tremblay, Blanchard, Taylor, Pelletier ve Villeneuve (2009) tarafindan geliştirilen İçsel ve Dışsal Güdülenme Ölçeğinin Türkçeye uyarlamasl, güvenilirlik ve geçerliliğinin test edilmesi amaçlanmıștır. Araștırmada çalıșanlardan olușan iki farklı örneklem (Şirket çalışanı $n_{1}=123$ ve Akademisyen $n_{2}=518$ ) kullanılmıştır. Analizler sonucunda ölçeğin alt boyutlarının birinci örneklemde güvenilirlik değerlerinin .53 ile .86 arasında, ikinci örneklemde ise .58 ile .89 arasında değiştiği gözlemlenmiştir. Ölçeğin altı faktörlü yapısı (tanımlanmıș, içsel, içselleștirilmiș, yansitılmış, dıșsal ve güdülenmeme) yapılan doğrulayıcı faktör analizleriyle doğrulanmıştır. Ölçeğin ölçüt bă̆ımlı geçerliliği rol performansı ile test edilmiştir. Ayrıca ölçeğin cinsiyet açısından yapısal ve ölçümsel olarak ayrıșmadı̆̆ tespit edilmiştir. Tüm bulgular, içsel ve dışsal güdülenme ölçeğinin gelecekte yapılacak çalışmalarda güvenilir ve geçerli bir ölçüm aracı olarak kullanılabileceğini göstermiştir.

\footnotetext{
a Bu çalışmanın pilot çalışması 3-5 Eylül 2020 tarihlerinde düzenlenen 28.Yönetim ve Organizasyon Kongresi'nde "İçsel ve Dışsal Güdülenme Ölçeğinin Türkçeye Uyarlaması: Bir Pilot Çalışma” başlıklı bildiri olarak sunulmuştur. Araştırmanın ikinci örneklemine ait veriler ikinci yazarın "Algllanan Örgütsel Kimliğin ve İçsel-Dışsal Güdülenmenin Rol İçi ve Rol Dışı Performansa Etkileri: Konya Ovası Projesi Bölgesi Üniversitelerinde Bir Araştırma” adlı doktora tezinden bă̆ımsız değildir.

${ }^{\mathrm{b}}$ Prof. Dr., Niğde Ömer Halisdemir Üniversitesi, İI.̇.B.F, İsletme Bölümü, fatih_cetin@ymail.com, ORCID:0000-0002-2487-9553

c Sorumlu Yazar, Dr. Öğr. Üyesi, Karamanoğlu Mehmetbey Üniversitesi, Sosyal Bilimler MYO, Yönetim ve Organizasyon Bölümü, muhammetalicelebi@gmail.com, ORCID:0000-0003-3892-1879
} 


\section{KAVRAMSAL ÇERÇEVE}

\section{GİRIS}

Örgüt psikolojisi alanındaki en zorlu ve değişmeyen konuların başında çalıșanların nasıl güdüleneceği sorusu gelmektedir. Güdülenme çalş̧an davranışlarının yönünü, yoğunluğunu ve kararlılığına yön veren gücü ifade etmektedir (Pinder, 2008). Literatürde güdülenme konusu farklı bakış açılarıyla ve birçok yönüyle ele alınmış olmasına rağmen "zevk aldiğın bir işi yaptı̆̆ında yaşaminda bir gün bile çalışmak zorunda kalmazsın" söylemi içsel güdülenmenin bu süreçteki önemine işaret etmektedir. İçsel güdülenme, belli bir sonuca ulaşmak için bir eylemde bulunmayla ilişkili dişsal güdülenmeden farklı olarak, eylemi yapmaktan kaynaklanan zevk ve ilgi ile ilişkilidir. Bunlara ilaveten güdülenmeme durumunu da içine alarak öne sürülen bir model, çalışanların çok farklı ve kişisel dişsal nedenlerinden dolayı zaman ve enerjilerini belirli davranışlara yönelttiklerini öne sürmektedir. ÖzBelirleme Teorisi (Self-Determination Theory) bu çerçevede kişisel nedenleri: kişi eylemi anlamlı bulduğunda tanımlanmış, eylemi yapmak ilginç ve zevkli olduğunda içsel, kişinin kendilik algısı ve değerleriyle ilişkisi olduğunda içselleştirilmiş, kendiliğini zorla katıp baskılayarak yansıtılmış, diğerleri tarafindan zorlandığında dışsal ve güdülenmeme biçiminde açıklamaktadır. Esasında bu farklı türlerdeki güdülenme daha kontrollü süreçler ile kendi kendine veya daha kontrol altında olan güdülenmeyi ifade ederek öz-belirleme sürecinin aşamalarını ifade etmektedir.

$\mathrm{Bu}$ güdülenme modeli her ne kadar birbirinden farklı yapılarla kavramsallaştırılsa da örgütsel davranış araştırmalarındaki kullanımı ve sonuçları konusunda yeterli çalışma bulunmamaktadır. Bu durumun temel sebeplerinden birisi yapilar arasındaki ilişkilerden kaynaklanan ortak çoklu bağıntılılık problemlerinin ortaya çıkması, ayrıca her bir güdülenme yapısının hangi farklı sonuçlarla ilişkilerinin olduğu konusu da tam olarak aydınlığa kavuşturulamamış olmasıdır. Mevcut çalışma yazındaki bu boşluğu kapatmak amacıyla gelecekteki çalışmalarda kullanılabilecek Tremblay ve arkadaşları (2009) tarafından geliştirilen İçsel ve Dıșsal Güdülenme Ölçeği'nin ulusal yazına kazandırılmasını amaçlamaktadır. Böylelikle güdülenme sürecini yalnızca içsel ve dışsal biçiminde ayırmanın ötesinde, içsel, tanımlanmış, içselleştirilmiş, yansitılmış, dışsal ve güdülenmeme boyutlarla güdülenme süreçlerinin daha iyi anlaşılmasına ve çeşitli sonuçlarla ilişkilendirilmesine olanak verebilecektir.
Güdülenme kişinin davranışta bulunmayı isteme derecesi ve meşgul olmayı seçmesi olarak tanımlanmaktadır (Mitchell, 1982). İş ortamında güdülenme ise, kişinin işi hakkında ne yaptığ (yön), ne kadar çalıştığı (yoğunluk) ve işini ne kadar sürdürdüğüyle (kalıcılığı) ilgili bilgileri içeren süreci kapsamaktadır (Kanfer, 1990).

Güdülenme üzerine yapılan teori ve araştırmalar, ihtiyaçlara, hedeflere, beklentilere ve kişinin ödüllendirici bulduğu sonuçlara odaklanmaktadır (Ellemers, Gilder, \& Haslam, 2004). Öz Belirleme Teorisi, içsel ve dışsal güdülenme arasındaki ayrımı incelemesi nedeniyle öne çıkan güdülenme teorileri arasındadır. Öz Belirleme Teorisi kişilerin kendi kendilerine güdülenmeleri temel alan, doğuştan gelen eğilimlerini ve psikolojik ihtiyaçlarını etkileyen koşulları araştırmaktadır. Teori; kişinin davranışa katılmaktan elde edeceği zevk ve tatminde ve doğuştan gelen psikolojik ihtiyaçlarının karşılandığını hissettikleri zamanda içsel olarak güdülendiğini ileri sürmektedir. Buna karşıllk kişinin dışsal olarak güdülenmesi durumunda, ayrılabilir sonuçlara veya dış ödüllere ulaşmak için kișinin bir davranıșta bulunmayı tercih etmesi anlamina gelmektedir (Ingledew, Markland, \& Sheppard, 2004).

Öz Belirleme Teorisini geliştiren teorisyenlerden Deci (1972), içsel güdüleyicileri kişinin kendisi tarafından yönetilen, dışsal güdüleyicileri ise diğerleri tarafindan yönlendirilen süreçler olarak tanımlamaktadır. Porter ve Lawler (1968) içsel güdülenmeyi, bir aktiviteyi ilginç bulduğu için yapan kişilerin işe olan ilgilerinden dolayı kendiliğinden tatmin oldukları güdülenme biçimi olarak ifade etmektedir. Dışsal güdülenmeyi ise eylemin kendisinden değil, eylemin yol açtığ 1 dışsal sonuçlardan kaynaklanan somut veya sözel ödüller gibi araçsallarla açıklamaktadır (Gagné \& Deci, 2005).

Öz Belirleme Teorisi ilk zamanlarda içsel güdülenmeye odaklansa da zamanla dișsal güdülenmeyi de kapsayacak şekilde gelişmiştir. Teori güdülenmenin "doğasına" yani davranış nedenine odaklanarak (Tremblay, vd., 2009), psikolojik ihtiyaçları özerklik, yeterlilik ve ilişkili olma ihtiyaçları olarak incelemektedir (Ryan \& Deci, 2000b). Psikolojik temel ihtiyaçlardan ilki olan özerklik, davranışın dış koşullardan ziyade kișinin kendisi tarafından ne ölçüde istemli olarak hissedildiğini anlamaya yöneliktir (Stupnisky, BrckaLorenz, \& Laird, 2019). Özerklik kişinin kendi davranışlarını aktif olarak belirlemesini ve başkalarının etkisi olmadan ustalık deneyimini 
yaşama ihtiyacını yansıtmaktadır (Arshadia, 2010). Özerklik irade duygusu ile hareket etmeyi ve seçme deneyimine sahip olmayı içermektedir. İçsel güdülenme çoğunlukla özerklik güdüsüyle ilişkilendirilmektedir. Kişinin ilginç bulduğu için bir etkinliğe katılması ve tamamen istemli olarak hareket etmesi, örneğin "ben çalışırken eğleniyorum" demesi, içsel olarak güdülendiğini göstermektedir (Gagné \& Deci, 2005). İkinci psikolojik ihtiyaç, kişinin çevresiyle etkili bir şekilde etkileşim kurma isteği olan yeterliliktir. Yeterlilik, zorluklarla yüzleşme, üstesinden gelme ve öz-yeterlilik algısını teşvik eden geri bildirimleri alma suretiyle gelişmektedir (Stupnisky vd., 2019). Yeterlilik, çalışma ortamında kişinin enerjisini ve yetkinliğini verimli kullanması ve rol sorumluluklarını iyi bir şekilde yerine getirmesine yönelik ihtiyacı açıklamaktadır (Arshadia, 2010). Üçüncü psikolojik ihtiyaç olan ilişkili olma duygusu, diğerleri ile olan olumlu bağlantıları ve aidiyet duygusu deneyimlerini içermektedir (Stupnisky vd., 2019). İlişkili olma duygusal olarak sevme, sevilme, bir arada olma, onaylanma ve bağlanma gibi diğerleriyle anlamlı ilişkiler kurma ihtiyacını yansitmaktadır (Arshadia, 2010).

Öz Belirleme Teorisi, yukarıda ifade edilen üç temel psikolojik ihtiyaçların karşılanma derecesine göre kişilerin eylemlerini içselleştirdiğini öne sürmektedir (Ryan \& Deci, 2000a). Böylelikle içselleştirilmiş güdülerle davranışı yerine getirerek, kişiler kendi seçtikleri amacın bir parçası olduklarını hissetmektedirler. Buna karşın üç temel psikolojik ihtiyacın tatmin edilmemesi veya bir dereceye kadar engellenmesi durumunda ise kontrollü bir şekilde dişsal güdüleyiciler kişiyi harekete geçirmektedir (Stupnisky vd., 2019).

Öz Belirleme Teorisi'yle ilişkili olan Organizma Entegrasyonu Teorisi, dişsal güdülenmenin farklı biçimlerini ve içselleştirmeyi teşvik eden veya engelleyen bağlamsal faktörleri ayrıntılarıyla açıklamaktadır. Şekil 1'de soldan sağa doğru düzenlenen güdülenme türlerinin Organizma Entegrasyonu Teorisi çerçevesinde sınıflandırması yer almaktadır (Deci \& Ryan, 1985; Deci \& Ryan, 2000b). Güdülenme türleri kişinin eyleme katılma gerekçelerini veya nedenlerini yansıtmaktadır. Yapılan davranış kişinin psikolojik ihtiyaçlarına hizmet edip etmeyeceğine ilişkin algılar tarafından şekillenmektedir. Şekil 1'e bakıldığında yansıtılmış, tanımlanmış, içselleştirilmiş ve dişsal olarak davranışın düzenlenmesinin dişsal güdülenmeyi oluşturduğu görülmektedir. İçsel olarak kişinin tam bir özerklik ile dışarıdan herhangi bir kaynağın kontrolü olmadan davranışı seçme arzusu ise içsel güdülenmeyi tanımlamaktadır. Güdülenmeme ise harekete geçme niyeti bulunmayan eylemsizlik halini tanımlamaktadır.
Öz Belirleme Teorisi ayrıca güdülenmeyi özerk ve kontrollü güdülenme olarak ikili bir ayrımda incelemektedir. Kontrollü güdülenme genellikle tükenme ve olumsuz etki gibi daha olumsuz deneyimlerle ilişkilendirilirken, özerk güdülenme daha fazla keyif ve memnuniyet duygusuyla ilişkilendirilmektedir (Deci \& Ryan, 2000; Ryan \& Deci, 2017; Nguyen, Weinstein, \& Ryan 2021). İçsel güdülenme özerk güdülenmeyi tanımlarken, dışsal yansıtılmış, tanımlanmış ve içselleştirilmiş güdülenme kontrollü güdülenmeyi tanımlamaktadır.

\subsection{Güdülenme Boyutları}

İcsel Güdülenme. İçsel güdülenme bir şey yapma arzusu olarak tanımlanmaktadır. Kişinin işinde kararlı ve yetkin olduğunu hissettiğinde, öğrenmek için çaba harcadığında, kendisini geliştirmek istediğinde ve yeni beceriler edinmek istediğinde içsel olarak güdülendiği görülmektedir (Ryan \& Deci, 2000b). İçsel güdülenmede kişi kendisi için bir aktiviteyi ilginç ve zevkli olarak tanımlamaktadır. Kişinin belli bir sonuca (kişisel başarı, artan bilgi, vb.) ulaşmak için yapmış olduğu davranış sonucunda elde ettiği zevk ve tatmin olma durumları, içsel olarak güdülendiğini göstermektedir (Ryan \& Deci, 2000a).

Dışsal Güdülenme. Deci ve Ryan'a göre dişsal güdülenme, dış kaynaklara dayalı olarak belirli şekillerde davranmaya yönelik bir dürtüdür ve dışsal ödüllerle sonuçlanmaktadır (Deci \& Ryan, 1985). Bu tür kaynaklar, derecelendirme sistemlerini, çalışan değerlendirmelerini, ödülleri, övgüleri, başkalarının saygısını ve hayranlığını içerebilmektedir. Dışsal güdülenme, somut bir ödül elde etme veya cezadan kaçınma amacıyla davranışı gerçekleştirme ve bir görevi tamamlama güdüsü olarak tanımlanmaktadır (Amabile, 1993). Ödül ve onay alma, cezadan ve eleştiriden kaçınma, kişinin benlik saygısını yükseltme ya da kişisel olarak değerli bulduğu hedefe ulaşma gibi araçsal nedenlerle aktiviteye katılması dışsal güdülenmeyi tanımlamaktadır (Gagné vd., 2015).

Dışsal güdülenme, kişiye vaat edilen ödüller veya beklenen değerlendirmeler gibi işin dışında gerçekleşen durumlarda ve kişinin diğerleri tarafından kendisinin yönlendirildiğini hissettiği anlarda görülmektedir. Amabile (1993) dişsal güdüleyicileri, işin bir parçası olmayan, işin başlangıcını veya icraatını kontrol etmek amacıyla bir dış kaynaktan gelen (örn: övgü, vaat edilen ödül, görevin bitirilmesi için verilen son tarih, gözetleme, kritik geri bildirim, vb.) faktörler olarak nitelendirmektedir (Amabile, 1993). 


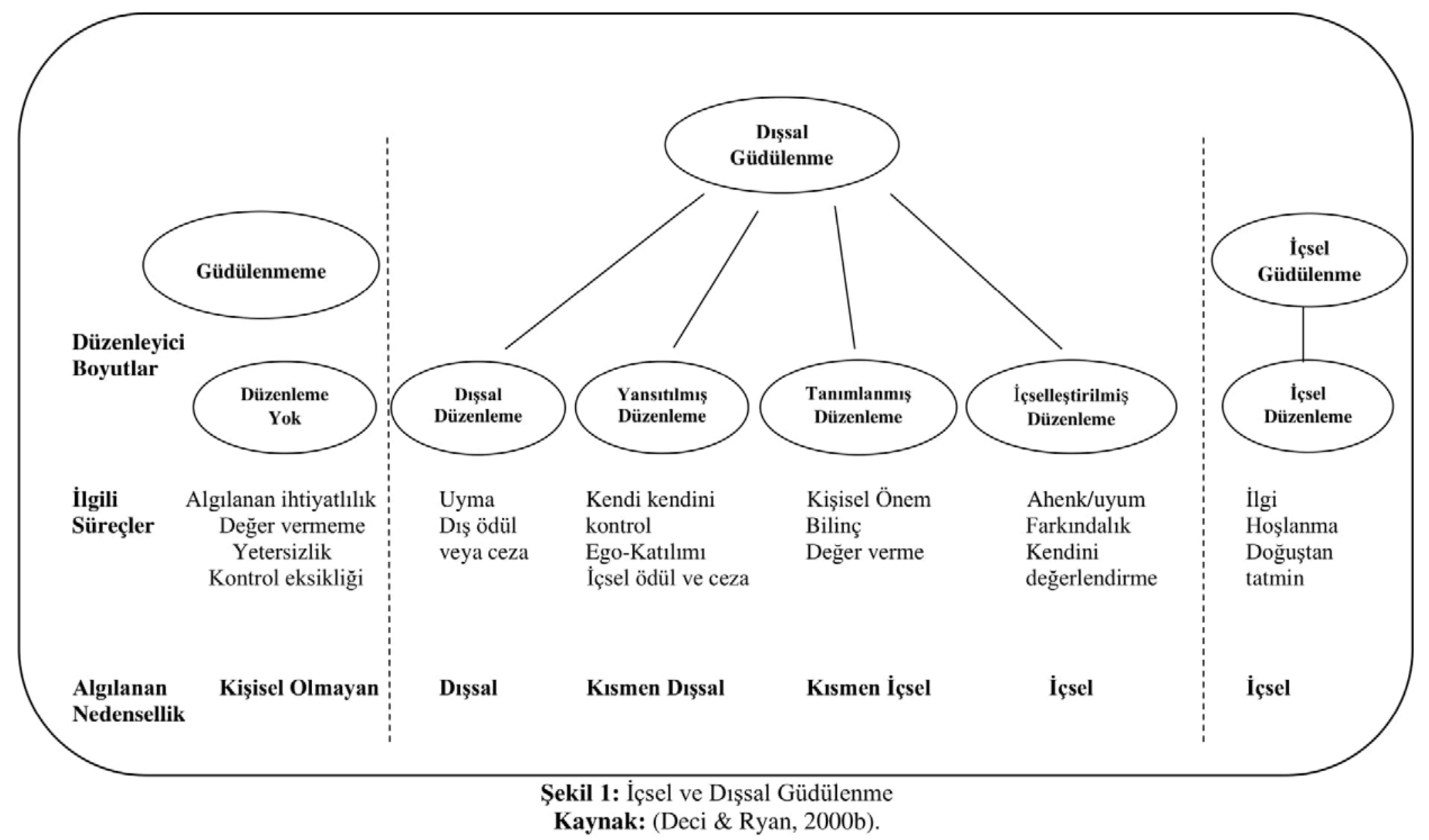


Yansıtılmış Güdülenme. Suçluluk veya öz değer duyguları gibi iç baskılar nedeniyle ortaya çıkan davranışlar yansitılmış güdülenme içinde incelenmektedir. Kısmi içselleştirme sonucu gerçekleşen yansıtılmış güdülenmede davranışın nedeninde "yapıyoruz çünkü yapmazsak yapmadı̆̆ımız için utanacă̆ız veya düş kırıklı̆̆ yaşayacağız” gibi nedenler yatmaktadır. Yansitılmış güdülenmede davranış içe yansıtıldığında dış etkenlere açık olmadığından içseldir, ancak henüz kişinin benliğinin bir parçası olmamıştır. Yansıtılmış güdülenme bir çeşit içsel güdülenmedir, ancak algılanan nedenselliğin dışsal ve kısmen kontrol altında olması bu güdülenme türünün dişsal güdülenme içerisinde incelenmesini sağlamıştır (Decharms, 1968; Vallerand vd., 1989, Ryan \& Connell, 1989, Rigby vd., 1992, Boiche \& Sarrazin, 2007; Akt: Kara, 2008).

Yansitılmış güdüler konusunda kişi "yapılmalı" ve "yapılmast zorunlu" gibi mesajların etkisi altındadır. Diğgerlerinin beklentileri esasında içsel olarak değerli olmadığı gibi anlamlı da değildir. Çünkü bu durum diğerlerinin baskılayıcı davranışlarından kaynaklanan beklentilerin bir birikintisidir (Ryan \& Deci, 2017; Nguyen, Weinstein, \& Ryan 2021). Kişi yalnız kaldığında, etrafında ona ne yapacağını söyleyecek kimse yokken, yaşamış olduğu deneyimler itici bir güç olarak içe yansıtılmış düzenlemeyi ortaya çıkarabilmektedir. Yansıtılmış güdülenmede kişi, kısmen dişsal etkenleri kontrol edebilmekte davranışı kısmen kendi kendine belirlemektedir. $\mathrm{Bu}$ çerçevede kişinin benlik saygısını, değer hissini ve kendilik gelişimini artırması veya sürdürmesi amacıyla eylem gerçekleştirmesi yansıtılmış güdülenme içinde değerlendirilmektedir (Ryan, 1982, Nicholls, 1984: Akt: Ryan \& Deci, 2000a).

Tanımlanmış Güdülenme. Kişinin davranışının nedenini sorguladığı, davranışı yapması gerektiğini düşündüğü için yapmayıp, daha çok davranışın değeriyle tanımlayıp yaptığı güdülenme boyutudur. Tanımlanmış güdülenmede kişinin kendisine belirlediği amaç için bu davranışı önemsediği görülmektedir (Boiche \& Sarrazin, 2007; Akt: Kara, 2008). Bu güdülenme türünde kişi davranışın kişisel önemiyle özdeşleşmekte ve bu nedenle düzenlemeyi kendi davranışı olarak kabul etmektedir (Ryan \& Deci, 2000a). Tanımlanmış güdülenmede kişi eylemlerine kişisel bir gerekçe ürettiği (mantığa bürüdüğü) için, davranışlarını ve eylemlerini hem seçme hem de sürdürme konusunda daha özerk bir şekilde düzenlemek ve esnekliğe sahip olmak istemektedir (Deci, Olafsen, \& Ryan, (2017). Kişinin ulaşmak istediği amaçlar ve elde etmek istediği yaşam standartları nedeniyle eylemlerini yerine getirmesi tanımlanmış güdülenmeyi işaret etmektedir.
Davranışın değerinin ve öneminin bilindiği, kabul edildiği ve bunun kendilikle entegrasyonunun sağlandığı süreçler tanımlanmış güdülenmeyle açıklanmaktadır (Burton, Lydon, D’Alessandro, \& Koestner, 2006). Tanımlanmış güdülenme yapılmak istenilen aktivitenin içten gelen bir tatminden kaynaklanmayıp, temsil ettiği araçsal değer için yapılması bakımından güdülenmeyi açıklamakta ve bu nedenle içsel güdülenmeden farklılaşmaktadır (Gagné vd., 2015).

İçselleştirilmiş Güdülenme. Tanımlanmış güdülenme içinde yer alan düzenlemeler tamamen özümsendiğinde gerçekleşen güdülenme türü içselleştirilmiş güdülenmedir. Kişinin kendi kendini değerlendirerek yeni düzenlemeleri kendi değerleri ve ihtiyaçlarıyla uyumlu hale getirmesi, içselleştirmesiyle mümkün olmaktadır. Burada eylemin nedenlerinin anlaşılması içselleştirmeyi kolaylaştırmaktadır (Ryan \& Deci, 2000a). Özdeşleşmiş değerlerin ve kuralların bütünleştirilmesi ya da özümsenmesi sonucu olarak ortaya çıkan davranışlarda içselleştirilmiş güdülenme görülmektedir (Boiche \& Sarrazin, 2007). Kişi tamamen içselleştirdiğinde gerçek bir istem ya da iradeyle davranmaktadır. İçselleştirme sonucu düzenlenen davranışlar dişsal düzenlemenin en olgun ve tamamen içsel olarak belirlenmiş şeklidir (Kara, 2008).

İçselleştirilmiş güdülenmede içsel kaynaklar ve kendinin farkında olma arzusu kişilerin davranışına rehberlik etmektedir. Davranış içselleştirilmiş olarak düzenlendiğinden, kişi benlik duygusuyla tamamen uyumlu olduğu için davranışa geçmektedir. İçselleştirilmiş güdülenme, davranışın hiçbir zorlama duygusu olmadan (harici veya içsel olarak dayatılan) yapılması ve bu nedenle tamamen kişinin kendi kendine belirlemesi bakımından içsel güdülenmeye benzemektedir. İçselleştirilmiş güdülenmede davranışın, bizzat kendi başına aktivitede bulunmanın doğasında yer alan tatminden ziyade, ayrılabilir sonuçlara ulaşmak için yapılması nedeniyle, içsel güdülenmeden farklılaşmaktadır (Ingledew, Markland \& Sheppard 2004). Kişinin davranışı gerçekleştirirken, yaşam biçimiyle, yaşamının bir parçasıyla veya kim olduğuyla ilişkilendirmesi içsel güdülenme ile içselleştirilmiş güdülenme arasındaki ayrımı kolaylaştırmaktadır.

Güdülenmeme. Kişinin davranış ve sonuçları arasında hiçbir ilişki görmeyerek, davranışa yönelik olarak hissettiği isteksizlik güdülenmemeyi anlatmaktadır (Boiché \& Sarrazin, 2007). Güdülenmemede kişi, davranış niyetinden ve kişisel nedensellikten yoksundur. Güdülenmeme, bir aktiviteye değer vermemekten (Ryan, 1995), bunu yapmaya yetkin hissetmemekten (Deci, 1975) veya bunun istenen bir sonuca ulaşacağına kişinin 
inanmamasından (Seligman,

kaynaklanmaktadır (Ryan \& Deci, 2000a).

\section{2. İçsel ve Dışsal Güdülenme Ölçeği}

İçsel ve dişsal güdülenme ölçeği, Tremblay ve arkadaşları (2009) tarafından, iki farklı (asker ve sivil çalışanlar) örneklemden veri toplanarak geliştirilmiştir. Ölçek iş özellikleri, çalışan güdülenmesi ve örgütsel işleyiş arasındaki etkileşimin daha iyi anlaşılmasına katkıda bulunacağ1 düşüncesiyle, Öz Belirleme Teorisi temel alınarak geliştirilmiştir (Tremblay vd., 2009). Ölçekte, tanımlanmış, içsel, yansıtılmış, içselleştirilmiş, dişsal ve güdülenmeme olmak üzere altı boyut bulunmaktadır.

\section{YÖNTEM}

\section{1. Çeviri Çalışması}

İçsel ve dışsal güdülenme ölçeğinin kullanımı için ölçeği geliştiren yazarlara e-posta yolu ile izin talebinde bulunulmuş ve Pelletier'in olumlu yanıt vermesi üzerine ölçek kullanılmıştır. Ölçeğin çeviri süreci hedef dile ilk çevirinin yapılması, ilk çevirinin değerlendirilmesi, kaynak dile geri çeviri, geri çevirinin tekrar değerlendirilmesi ve alanında yeterlilik sahibi bir uzman görüşüne danışma adımlarından oluşmaktadır (Brislin, 1986). İlk olarak ölçeğin orijinal formu iki İngilizce dil yeterliliğine sahip uzmana gönderilerek Türkçeye çevirisinin yapılması sağlanmıştır. İki alan uzmanı tarafından elde edilen çevirilerin alan yazını açısından uygunluğu değerlendirilmiştir. Elde edilen Türkçe form kaynak dile geri çevrilmesi aşaması için iki adet İngilizce yeterliliği olan uzmana gönderilmiştir. Uzmanlardan gelen İngilizce form ile orijinal form karşılaştırılarak ölçeğin dil geçerliliğinin sağlanıp sağlanmadığı kontrol edilmiştir. Çeviri çalışmasının son aşamasında alana hâkim olan bir uzman tarafindan genel bir değerlendirme yapması istenmiştir. Değerlendirme sonucunda ölçeğin anlaşılır olduğu, uygulanmasında bir sakınca olmadığı belirtilerek ölçek kullanılmıștır.

\section{2. Örneklem}

Birinci Örneklem. Ölçeğin Türkçeye uyarlanması çalışmasında birinci örneklemi, İstanbul'da faaliyet gösteren özel bir şirket çalışanları oluşturmaktadır. Şirkette \%13'ü kadın $(n=16), \% 87$ 'si erkek (n=107), \%56,9'u evli (n=67), \%35,8'i bekar $(n=44) \% 5,7$ 'si eșinden ayrılmıș $(n=7)$ ve \%1,6's1 eşi vefat etmiş $(n=2)$ olmak üzere toplam 123 çalışandan veri toplanmıştır.
İkinci Örneklem. Çalışmada ikinci örneklem üniversitelerde çalışan akademik personel oluşturmaktadır. Selçuk Üniversitesi $(n=82)$, Nevşehir H. Bektaş Üniversitesi ( $\mathrm{n}=73)$, Kırıkkale Üniversitesi $\quad(n=62), \quad$ Necmettin Erbakan Üniversitesi $(n=59)$, Karamanoğlu Mehmetbey Üniversitesi ( $n=55)$, Ahi Evran Üniversitesi $(n=53)$, Bozok Üniversitesi $(n=50)$, Aksaray Üniversitesi $(n=34)$, Niğde Ömer Halisdemir Üniversitesi $(\mathrm{n}=45)$, Konya Gıda ve Tarım Üniversitesi'nde $(n=5)$ çalışan 518 akademisyen araştırmaya katılmıştır. Akademisyenlerin, \%39,4'ü kadın ( $n=204)$, \%58,3'ü erkek (n=302), \%72,9'u evli $(n=377), \% 25,3$ 'ü bekar $(n=131)$ ve \%1,7'si eşinden ayrılmıştır $(n=9)$.

\subsection{Veri Toplama Araçları}

İcsel ve Dışsal Güdülenme Ölçeği. Tremblay ve arkadaşları (2009) tarafından geliştirilen içsel ve dışsal güdülenme ölçeği altı boyuttan ve onsekiz maddeden oluşmaktadır. Ölçekte her bir boyutu (tanımlanmış, içsel, içselleştirilmiş, yansıtılmış, dışsal ve güdülenmeme) teorik olarak tanımlayan üç madde bulunmaktadır. Güdülenme düzeyinin ölçülmesinde 5'li Likert tipinde değerlendirme skalası kullanılmıştır (1=kesinlikle katılmıyorum, 5=tamamen katıliyorum).

Rol Performansı Ölçeği. Sigler ve Pearson (2000)'ın, dört maddelik rol performansı ölçeği, içsel ve dişsal güdülenme ölçeğinin geçerliliğini test etmek amacıyla araştırmada kullanılmıştır (Sigler \& Pearson, 2000). Tek boyutlu rol performans1 ölçeğinin güvenilirlik değeri (Cronbach Alfa) .784 olarak hesaplanmıştır.

\section{BULGULAR}

\section{1. İstatiksel Analiz}

Araștırmada elde edilen verilerin incelenmesinde IBM SPSS 24.0 ve Amos 24.0 istatistik paket programları tercih edilmiştir. Ölçek geçerliliği için önce doğrulayıcı faktör analizi (DFA) yapılmış ve yap1 geçerliliği test edilmiştir. Sonra ölçüt bağımlı geçerlilik analizi yapılarak elde edilen bulgular desteklenmiştir. Ölçeğin güvenilirliği için ise, iç tutarlılığı gösteren Cronbach Alfa katsayısı iki örneklemde genel ve boyutsal olarak hesaplanmıştır.

Geçerlilik ve güvenilirlik analizlerinden önce araştırma verilerinin normal dağılıp dağılmadığına bakmak ve dağılımlarının biçimlerini ortaya çıkarılması gerekmektedir. Bunun için verilerin çarpıklı (skewness) ve basıklık (kurtosis) değerlerine bakılmıştır. Tablo 1'e bakıldığında 
Tablo 1: İçsel ve Dışsal Güdülenme Ölçeğinin Madde Tepki İstatistikleri

\begin{tabular}{|c|c|c|c|c|c|c|c|c|c|c|c|c|}
\hline & \multicolumn{4}{|c|}{ Toplam Örneklem $(\mathrm{n}=641)$} & \multicolumn{4}{|c|}{ Birinci Örneklem $(n=123)$} & \multicolumn{4}{|c|}{ İkinci Örneklem (n=518) } \\
\hline & Ort. & $S S$ & Çarp. & Bas. & Ort. & SS & Çarp. & Bas. & Ort. & SS & Çarp. & Bas. \\
\hline Mad.1 & 3.598 & 1.0891 & -.773 & -.206 & 3.969 & 1.0448 & -1.247 & 1.195 & 3.511 & 1.0819 & -0.708 & -0.353 \\
\hline Mad.2 & 4.025 & .9148 & -1.093 & 1.092 & 4.073 & .8700 & -1.206 & 1.943 & 4.013 & 0.9256 & -1.070 & 0.945 \\
\hline Mad.3 & 3.903 & .9117 & -.874 & .510 & 4.000 & .9496 & -.933 & .630 & 3.880 & 0.9019 & -0.873 & 0.511 \\
\hline Mad.4 & 4.321 & .8458 & -1.644 & 3.291 & 3.878 & 1.1422 & -1.132 & .627 & 4.427 & 0.7209 & -1.529 & 3.271 \\
\hline Mad.5 & 3.822 & 1.0044 & -.816 & .201 & 3.642 & 1.1744 & -.657 & -.459 & 3.865 & 0.9560 & -0.820 & 0.333 \\
\hline Mad.6 & 3.838 & .9962 & -.754 & .102 & 3.894 & 1.1000 & -.952 & .258 & 3.824 & 0.9705 & -0.699 & 0.053 \\
\hline Mad.7 & 4.042 & .8328 & -.893 & .972 & 3.764 & .9924 & -.481 & -.330 & 4.108 & 0.7768 & -0.960 & 1.499 \\
\hline Mad. 8 & 4.012 & .8292 & -.929 & 1.271 & 3.721 & 1.0264 & -.707 & .266 & 4.081 & 0.7600 & -0.854 & 1.235 \\
\hline Mad.9 & 3.765 & 1.0053 & -.683 & -.081 & 3.618 & 1.1560 & -.503 & -.583 & 3.800 & 0.9640 & -0.709 & 0.037 \\
\hline Mad.10 & 3.142 & 1.2042 & -.152 & -.926 & 3.081 & 1.3646 & -.031 & -1.153 & 3.157 & 1.1638 & -0.183 & -0.873 \\
\hline Mad.11 & 3.191 & 1.1784 & -.294 & -.862 & 3.049 & 1.3111 & -.157 & -1.084 & 3.224 & 1.1435 & -0.315 & -0.812 \\
\hline Mad.12 & 3.250 & 1.1524 & -.314 & -.793 & 3.885 & 1.1394 & -1.021 & .379 & 3.099 & 1.1039 & -0.248 & -0.811 \\
\hline Mad.13 & 3.126 & 1.1798 & -.275 & -.971 & 3.691 & 1.1883 & -.927 & .023 & 2.992 & 1.1384 & -0.190 & -1.012 \\
\hline Mad.14 & 3.142 & 1.1753 & -.306 & -.913 & 3.780 & 1.1201 & -1.084 & .545 & 2.990 & 1.1375 & -0.203 & -0.953 \\
\hline Mad.15 & 3.116 & 1.1260 & -.393 & -.757 & 3.187 & 1.2371 & -.284 & -.796 & 3.099 & 1.0986 & -0.442 & -0.772 \\
\hline Mad.16 & 2.183 & 1.1790 & .737 & -.478 & 2.106 & 1.2791 & .849 & -.525 & 2.201 & 1.1545 & 0.714 & -0.451 \\
\hline Mad.17 & 1.941 & 1.0693 & 1.034 & .357 & 1.992 & 1.1198 & .871 & -.241 & 1.929 & 1.0577 & 1.079 & 0.540 \\
\hline Mad.18 & 1.950 & 1.0280 & .941 & .232 & 2.236 & 1.1020 & .639 & -.364 & 1.882 & 0.9988 & 1.023 & 0.466 \\
\hline
\end{tabular}

Ort. $=$ Ortalama, SS = Standart sapma, Çarp. $=$ Çarpıklık değeri, Bas. $=$ Basıklık değeri

araştırmanın birinci örnekleminde $\quad(n=123)$ ölçekteki tüm 18 maddenin basıklık (kurtosis) ve çarpıklık (skewness) değerlerinin normal dağıldığ görülmüştür. İkinci örnekleme bakıldığında ise $(n=518)$ 4'üncü maddenin basıklık değerinin normal dağılmadığı (3.271) saptanmıştır. İki verinin birleştirildiği toplam veride $(n=641)$ ise yine 4'üncü maddenin basıklık değerinin normal dağılmadı̆̆ 1 (3.291) saptanmıştır. 4'üncü maddenin basıklık değerlerinin normal dağılım göstermemesi araştırma kısıtları içinde değerlendirilmiştir. Ancak tek örneklemde karşılaşılan bu durumun gelecekteki çalışmalarda test edilmesi gerekmektedir. İçsel ve Dişsal Güdülenme Ölçeğinin madde tepki istatistiklerinin yer aldığ 1 Tablo 1'de basıklık ve çarpıklık değerlerinin -1.96 ile +1.96 arasında değiştiği görülmektedir.

\section{2. Ölçeğin Geçerliliğine İlişkin Bulgular}

\subsection{1. Ölçeğin Yapı Geçerliliği}

Birinci Örnekleme Ait Bulgular. İçsel ve dışsal güdülenme ölçeğinin yapı geçerliliğini test etmek amacıyla IBM AMOS 24 istatistik paket programı kullanılarak her iki örneklemde doğrulayıcı faktör analizleri (DFA) yapılmıştır. Birinci örneklem verisinin analiz edilmesi sonucunda, model uyum değerlerinin $\quad(\chi 2=202.596, \quad \mathrm{p}<.000, \quad \mathrm{df}=120$, $\chi 2 / \mathrm{df}=1.688, \quad \mathrm{RMSEA}=.075, \quad \mathrm{CFI}=.913) \quad$ kabul edilebilir değerler aralığında olduğu görülmüştür. Modelin bir uyum değerinin ise (TLI=.890) kabul edilebilir sınıra çok yakın olduğu görülerek araştırma sınırlılıkları içerisinde değerlendirilmiştir. DFA sonucunda ölçeğin boyutlarına ait faktör yükleri .34 ile .95 değerleri arasında değişmektedir (Şekil 2).

İkinci Örnekleme Ait Bulgular. İkinci örneklemden $(\mathrm{n}=518)$ elde edilen verilerle yapılan DFA sonucunda, model uyum değerlerinin $(\chi 2=459.942, \quad \mathrm{p}<.000, \quad \mathrm{df}=120, \quad \chi 2 / \mathrm{df}=3.833$, RMSEA=.074, TLI=.907, CFI=.927) kabul edilebilir değerler aralığında olduğu görülmüştür. Şekil 2'de ölçek boyutlarına ait faktör yüklerinin .41 ile .98 değerleri arasında değiştiği görülmektedir. $\mathrm{Bu}$ bulgular içsel ve dişsal güdülenme ölçeğinin altı faktörlü yapısının birinci ve ikinci örneklemde doğrulandığını göstermektedir. 


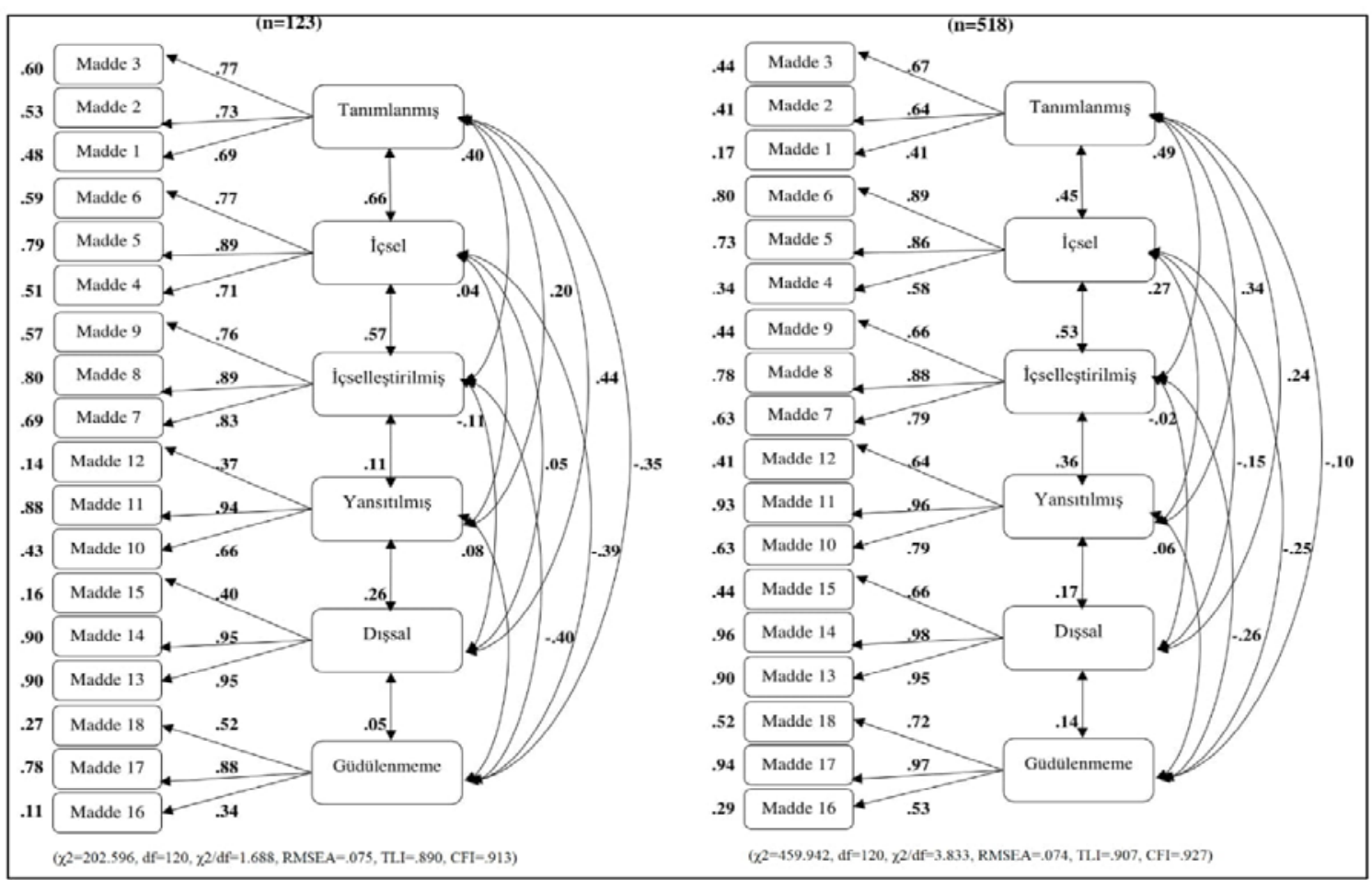

Şekil 2: İçsel ve Dışsal Güdülenme Ölçeğinin 18 Maddelik Faktör Yapısı

Ölçeği oluşturan maddelerden bazılarının faktör yüklerinin nispeten birinci örneklemde düşük değerler aldı̆̆ 1 (12. madde, 15. madde ve 16 . madde) ancak ikinci örneklem açısından incelendiğinde bu faktör yüklerinin nispeten yüksek değerler aldığı görülmüştür. $\mathrm{Bu}$ farklılı̆̆ın örneklemden kaynaklanan bir sonuç olabileceği değerlendirilmektedir.

\subsubsection{Benzeşim ve Ayrışım Geçerliliği}

Ölçeğin 'benzeşim' ve 'ayrışım' geçerliliğini göstermeleri açısından açıklanan ortalama varyans değerlerine (AVE) bakılmıştır. Fornell ve Larcker benzeşim geçerliliği için AVE değerlerinin 0.5 'ten büyük olması gerektiğini savunmaktadır (1981). Tablo 2'ye bakıldığında ölçeği oluşturan boyutlara ait AVE değerlerinin birinci örneklemde güdülenmeme boyutu (.39) hariç 0.5’ten yüksek olduğu görülmektedir. İkinci örneklemde yer alan AVE değerlerine bakıldığında ise tanımlanmış güdülenme boyutu (.34) hariç diğer boyutların kabul edilebilir değerden yüksek olduğu görülmüştür. İki boyuta (tanımlanmış ve güdülenmeme boyutları) ait düşük çıkan AVE değerleri araştırmada bir kısıt olarak değerlendirilmektedir. Ancak tanımlanmış ve güdülenmeme boyutlarına ait AVE değerlerinin her iki örneklemde aynı düşük sonuçlar üretmediği de görülmektedir. $\mathrm{Bu}$ durum boyutların açıklama yetersizliğini değil örneklem özelliklerinden kaynaklanan bir duruma işaret etmektedir. Gelecekteki çalışmalarda bu sonnuçların farklı örneklemlerde test edilmesi gerekmektedir. Ayrıca boyutlar arası ayrışım geçerliliği için AVE'nin karekök değerleri ile diğer boyutlar arasındaki ilişkiler karşılaştırılmıştır. Boyutlara ait AVE değerlerinin hesaplanan kareköklerinin boyutlar arası korelasyon değerlerinden büyük olma koşulu sağlanmıştır. Araştırma sonucunda elde edilen bu ilişkiler ölçeğin banzeşim ve ayrışım geçerliliği için yeterli kanıtın sağlandığını göstermektedir.

\subsection{3. Ölçüt Bağımlı Geçerliliği}

Araştırmada içsel ve dişsal güdülenme ölçeğinin geçerliliğinin test edilmesi amacıyla, ölçüt-bağımlı geçerliliğine bakılmıştır. Ölçüt-bağımlı geçerliği için test puanlarının bir dış ölçütle ilişkisi iki örneklemde $(n=123$ ve $n=518)$ incelenmiştir. Ölçeğin ölçüt-bağımlı geçerliliğini test etmek amacıyla, rol performans düzeyini ölçen ölçekle ilişkilerine bakılmıştır. Birinci örneklemde $(n=123)$ ölçeğin tanımlanmış, $(\mathrm{r}=.211, \mathrm{p}<.01)$ ve içsel $(\mathrm{r}=.274, \quad \mathrm{p}<.01)$ güdülenme boyutlarının rol performansı ile ilişkileri pozitif ve anlamlı çıkmıştır (Tablo 2). İçselleştirilmiş, yansıtılmış, dışsal ve güdülenmeme boyutları ile rol performansı arasında anlamlı ilişkilerin olmadığ 1 görülmüştür. İkinci örneklemde $(n=518)$ ise rol performansiyla tanımlanmış ( $\mathrm{r}=.197, \mathrm{p}<.01)$, içsel $(\mathrm{r}=.296, \mathrm{p}<.01)$, içselleştirilmiş $(\mathrm{r}=.317, \mathrm{p}<.01)$ ve yansitılmış $(\mathrm{r}=.088, \mathrm{p}<.05)$ güdülenme boyutları arasındaki ilişkiler pozitif, güdülenmeme $(\mathrm{r}=-.252, \mathrm{p}<.01)$ boyutuyla olan ilişkisi negatif çıkmıştır. Dışsal güdülenme ile rol performansı arasında anlamlı 
Tablo 2: Değişkenlerin Ortalamaları, Standart Sapmaları, Aralarındaki İlişkiler ve Açıklanan Ortalama Varyans Değerleri

\begin{tabular}{|c|c|c|c|c|c|c|c|c|c|c|}
\hline Birinci Örneklem $(n=123)$ & Ort. & $S S$ & $A V E$ & (1) & (2) & (3) & (4) & (5) & (6) & (7) \\
\hline Tanımlanmış güdülenme & 3.79 & .98 & .53 & $(.73)$ & & & & & & \\
\hline İçsel güdülenme & 4.01 & .79 & .63 & $.535 * *$ & $(.79)$ & & & & & \\
\hline İçselleştirilmiş güdülenme & 3.70 & .94 & .69 & $.505 * *$ & $.343^{* *}$ & $(.83)$ & & & & \\
\hline Yansıtılmış güdülenme & 3.34 & .99 & .49 & .156 & $.310^{\text {*** }}$ & .159 & $(.70)$ & & & \\
\hline Dışsal güdülenme & 3.55 & .98 & .66 & .052 & $.380^{* * *}$ & -.064 & $.301^{* *}$ & $(.81)$ & & \\
\hline Güdülenmeme & 2.11 & .84 & .39 & $-.308^{* * *}$ & $-.287 * *$ & $-.250 * *$ & -.018 & .022 & $(.62)$ & \\
\hline Rol Performansı & 4.05 & .56 & .48 & $.211^{* *}$ & $.274^{* * *}$ & .136 & .044 & .010 & -.047 & (.69) \\
\hline İkinci Örneklem $(\mathrm{n}=518)$ & Ort. & SS & $A V E$ & (1) & (2) & (3) & (4) & (5) & (6) & (7) \\
\hline Tanımlanmış güdülenme & 3.80 & .71 & .34 & $(.58)$ & & & & & & \\
\hline İçsel güdülenme & 4.03 & .75 & .62 & $.299 * *$ & $(.79)$ & & & & & \\
\hline İçselleştirilmiş güdülenme & 3.99 & .70 & .61 & $.334 * *$ & $.481 * *$ & $(.78)$ & & & & \\
\hline Yansıtılmış güdülenme & 3.16 & .98 & .65 & $.267 * *$ & $.204 * *$ & $.378^{* * *}$ & $(.81)$ & & & \\
\hline Dışsal güdülenme & 3.02 & 1.02 & .77 & $.288 * *$ & $-.140^{* * *}$ & -.009 & $.246 * *$ & $(.88)$ & & \\
\hline Güdülenmeme & 2.00 & .88 & .58 & -.037 & $-.239^{* * *}$ & $-.225^{* *}$ & $.096^{*}$ & $.172^{* *}$ & $(.76)$ & \\
\hline Rol Performansı & 4.16 & .60 & .55 & $.197 * *$ & $.296^{* *}$ & $.317 * *$ & $.088^{*}$ & -.010 & $-.252^{* *} *$ & (.74) \\
\hline
\end{tabular}

*p<.05, **p<.01, Parantez içindeki değerler AVE'nin hesaplanan karekök değerlerini göstermektedir.

ilişki tespit edilememiştir. Tüm bu sonuçlar ölçeğin ölçüt bağımlı geçerliliğine ilişkin kanıtlar sunmaktadır.

\subsection{4. Ölçeğin Yordama Geçerliliği}

Araştırmada ölçeğin yordama geçerliliğinin test edilmesinde güdülenmeyi oluşturan boyutlar ile performans arasında, her iki örneklem için ayrı ayrı regresyon analizi yapılmıştır. Tablo 3'e bakıldığında birinci örneklemdeki $(n=123)$ tanımlanmış güdülenme boyutunun performans değişkenini yordadığı $(\beta=.293, p<.01)$ diğer güdülenme boyutlarının ise yordamadığ 1 görülmüştür. İkinci örneklemde $(\mathrm{n}=518)$ içsel güdülenme boyutunun $(\beta=.147, \mathrm{p}<.01)$ ve içselleştirilmiş güdülenme boyutunun $(\beta=.190$, $\mathrm{p}<.01)$ performans üzerinde anlamlı etkisinin olduğu görülmüştür. Güdülenmeme boyutunun ise $(\beta=-.173, \mathrm{p}<.01)$ performansı olumsuz olarak etkilediği bulunmuştur. Tüm bu bulgular ilişkili alt boyutların yordama geçerliliğine ilişkin kanıtlar sunmaktadır.

Tablo 3: İçsel ve Dışsal Güdülenme Ölçeğinin Yordama Geçerliğine İlişkin Bulgular

\begin{tabular}{|c|c|c|c|c|c|c|c|c|c|c|}
\hline \multirow[b]{2}{*}{ Yordayan Değişkenler } & \multicolumn{5}{|c|}{ Birinci Örneklem $(n=123)$} & \multicolumn{5}{|c|}{ İkinci Örneklem(n=518) } \\
\hline & B & SS & $\beta$ & $\mathrm{t}$ & Sig & B & SS & $\beta$ & $\mathrm{t}$ & Sig \\
\hline Tanımlanmış & .209 & .085 & .293 & 2.447 & .016 & .069 & .039 & .082 & 1.768 & .078 \\
\hline İçsel & .045 & .067 & .078 & 672 & .503 & .116 & .038 & .147 & 3.025 & .003 \\
\hline İçselleştirilmiş & .007 & .063 & .011 & .107 & .915 & .161 & .043 & .190 & 3.750 & .000 \\
\hline Yansıtılmış & -.017 & .055 & -.030 & -.317 & .752 & -.016 & .028 & -.026 & -.559 & .577 \\
\hline Dışsal & -.056 & .058 & -.098 & -.959 & .340 & .015 & .027 & .025 & .554 & .580 \\
\hline Güdülenmeme & .044 & .064 & .065 & .687 & .493 & -.118 & .029 & -.173 & -4.002 & .000 \\
\hline & \multicolumn{10}{|c|}{ Rol Performansı (Yordanan Değişken) } \\
\hline
\end{tabular}




\section{3. Ölçeğin Güvenilirliğine İlișkin Bulgular}

Ölçeğin güvenilirlik analizinde, Cronbach Alfa katsayısı birinci örneklemde tanımlanmış güdülenme için .77, içsel güdülenme için .83, yansıtılmış güdülenme için .67, içselleştirilmiş güdülenme için .86 , dışsal güdülenme için .78 ve güdülenmeme alt boyutu için ise .53 olarak hesaplanmış, ölçeğin genelinde ise bu katsayı .73 bulunmuştur. İkinci örneklemde Cronbach Alfa katsayısı tanımlanmış güdülenme için .58, içsel güdülenme için .81 , yansıtılmış güdülenme için .83 , içselleştirilmiş güdülenme için $.80, \mathrm{~d}$ işsal güdülenme için 89 ve güdülenmeme alt boyutu için ise .76 olarak bulunmuş, ölçeğe genel olarak bakıldığında ise bu katsayı .76 hesaplanmıştır. Birinci örneklemdeki güdülenmeme (.53) boyutu ile ikinci örneklemdeki tanımlanmış güdülenmenin (.58) hesaplanan katsayılarının .70 değerinden düşük çıkması alt boyutların tutarlılı̆̆ çalışmada bir kısıt oluşturmaktadır. Ancak her iki boyutun diğer örneklemdeki değerleri kabul edilebilir sınırlar içinde olduğu ve iki örneklemde ortak güvenilirliği düşük bir alt boyutun olmaması, gelecek çalışmalarda bu boyutların güvenilirliğinin tekrar test edilmesine ihtiyaç göstermektedir. Sonuç olarak elde edilen değerler ölçeğin güvenilirliğine ilişkin yeterli kanıtlar sunmaktadır.

Ayrıca ölçeğin Tablo 4'te madde-toplam puan korelasyonları incelendiğinde birinci örneklemde $(\mathrm{n}=123)$ ölçeğin $10,15,16,17$ ve 18'inci maddelerinin toplam puanla olan ilişkisi, görece olarak daha düşük olduğu görülmektedir. Ayrıca ölçeğin güvenilirlik değerleri için ölçekten madde çıkarıldığı takdirde güvenilirliği artıran bir madde bulunmamaktadır. Diğer örnekleme bakıldığında $(\mathrm{n}=518)$ ise ölçeğin $4,5,16,17$ ve 18 'inci maddelerinin toplam puanla olan ilişkisi, görece olarak daha düşük olduğu görülmektedir. İkinci örneklemde ölçekten madde çıkarıldığı takdirde güvenilirliği artıran bir madde bulunmadığ 1 yine Tablo 4'ten anlaşılmaktadır. $\mathrm{Bu}$ sonuçlar güdülenmeme boyutunun ölçeğin tüm içsel ve

Tablo 4: İçsel ve Dışsal Güdülenme Ölçeğinin Güvenirlik Analizine İlişkin Bulgular

\begin{tabular}{|c|c|c|c|c|c|c|c|}
\hline \multirow[b]{2}{*}{ Maddeler } & \multirow[b]{2}{*}{ Boyutlar } & \multicolumn{3}{|c|}{ Birinci Örneklem(n=123) } & \multicolumn{3}{|c|}{ İkinci Örneklem(n=518) } \\
\hline & & $(\alpha)$ & DMTK & $M C ̧ C A$ & $(\alpha)$ & DMTK & $M C ̧ C A$ \\
\hline Mad 1 & & & .559 & .701 & & .354 & .749 \\
\hline Mad.2 & Tanımlanmış & .768 & .463 & .712 & .577 & .354 & .749 \\
\hline Mad.3 & & & .521 & .706 & & .384 & .747 \\
\hline Mad.4 & & & .402 & .713 & & .208 & .759 \\
\hline Mad.5 & İçsel & .828 & .435 & .710 & .813 & .263 & .756 \\
\hline Mad.6 & & & .490 & .706 & & .321 & .751 \\
\hline Mad.7 & & & .368 & .717 & & .340 & .751 \\
\hline Mad.8 & İçselleştirilmiş & .861 & .363 & .718 & .800 & .343 & .751 \\
\hline Mad.9 & & & .420 & .711 & & .437 & .743 \\
\hline Mad.10 & & & .243 & .729 & & .449 & .740 \\
\hline Mad.11 & Yansıtılmış & .671 & .360 & .717 & .831 & .551 & .731 \\
\hline Mad.12 & & & .522 & .702 & & .567 & .730 \\
\hline Mad.13 & & & .401 & .713 & & .401 & .745 \\
\hline Mad 14 & Dışsal & .782 & .415 & .712 & .893 & .403 & .745 \\
\hline Mad15 & & & .224 & .730 & & .375 & .747 \\
\hline Mad.16 & & & -.068 & .758 & & .110 & .770 \\
\hline Mad.17 & Güdülenmeme & .533 & -.161 & .761 & .764 & .099 & .769 \\
\hline Mad.18 & & & -.119 & .757 & & .124 & .766 \\
\hline n Genel $\mathrm{Cr}$ & h's Alpha Katsayı & .733 & & & .761 & & \\
\hline
\end{tabular}

(a): Cronbach's Alpha Katsayısı, DMTK: Doğrulanmıș Madde Toplam Korelâsyonları, MÇCA: Madde Silinirse Cronbach's Alpha Katsayısı. 
dışsal güdülenme boyutlarıyla olan tutarlılığının düşük olduğunu veya onlardan farklı hareket ettiğini göstermektedir.

\section{4. Ölçeğin Cinsiyet Farksızlığına İlişkin Bulgular}

İçsel ve dışsal güdülenme ölçeğinin cinsiyet açısından farksızlığının testi için örneklemin tamamında $(n=629)$ doğrulayıcı faktör analizi yapılmıştır (Model 1). Teorik olarak öne sürülen modelin testi için yapılan analiz sonuçları bu modelin genel olarak yeterli seviyede uyum sağladığını ancak çok iyi seviyede olmadığını göstermiştir. $\mathrm{Bu}$ aşamada programın ürettiği tavsiyeler izlenerek üç sorunun farklı faktörlerle de ilişkilendirilmesi sonucu modelin teorik varsayıma çok iyi seviyede uyum sağladığı görülmüştür (Model 2). Bunlardan tanımlanmış güdülenme sorusu olan "Belirli bir yaşam biçimini (standardını) elde etmek amacıyla seçtiğim mesleğimin bir parçası olduğu için" ve yansitılmış güdülenme sorusu olan "Yaşamda bir "kazanan" olmak istediğim için" sorularının dışsal güdülenmeyle; içselleştirilmiş güdülenme sorusu olan "Benim kim olduğumun önemli bir parçasını oluşturduğu için" sorusunun yansitılmış güdülenmeyle de düşük seviyelerde ilişkili olduğu görülmüştür. $\mathrm{Bu}$ durum belirli bir yaşam tarzına veya sonuçlarına ulaşmayla ilişkili güdülenmenin, kişi içi otonom süreçlerle olabileceği gibi belirli sonuçlarla ilişkilendirilmiş dışsal süreçlerle de olabileceğine işaret edebilir. Ayrıca iş/meslek ile kişi arasında yüksek derecede uyum sürecinde içselleştirilmiş güdülenme söz konusu iken; bu uyumun nispeten düşük olması kişinin kendisini sürekli işine veya mesleğine göre kontrol etmesini gerektireceğinden yansıtılmış bir güdülenme söz konusu olabilecektir. Tüm bu açıklamalar yukarıda ifade edilen soruların bağlamsal ve kişisel faktörler açıdan farklılaştığını göstermekte ve gelecek çalışma bulgularının teyitine ihtiyaç duymaktadır.

Elde edilen bu model temel alınarak örneklem kadın ve erkek olarak iki gruba ayrılmıştır (Kadın n= 220, Erkek $n=409$ ). Model her iki grup için ayrı ayrı test edilerek her iki grupta aynı yapının doğrulanıp doğrulanmadığı test edilmiş ve elde edilen sonuçlar bu modelin her iki grup için de ayrı ayrı doğrulandığını göstermiştir (Kadın grubu testi için Model 3; Erkek grubu testi için Model 4). Bu aşamadan sonra kadın ve erkekler arasında doğrulanan model istatistiklerinin farksızlığına ilişkin sırayla ve birbirlerine eklenerek, modeldeki faktör yükleri, ölçüm sabitleri, yapıların varyansları ile aralarındaki kovaryanslar ve ölçüm hataları test edilmiştir. $\mathrm{Bu}$ amaçla ilk aşamada, örneklemin kadın ve erkek biçiminde iki gruba ayrılarak istatistiklere hiçbir kısıtlama getirilmeden oluşturulan kısıtlanmamış modelin uyum değerleri hesaplanmış (Model 5) ve sonraki modeller için bu temel model referans alınmıştır. Modeller arasındaki farksızlığın testi ki kare testiyle yapılmış ve anlamlılık değerinin en az p>.05 olması kriteri aranmıştır. Bu kriterin karşılanmadığı durumlarda, her test edilen model içinde eşitliği bozan faktör yükleri, ölçüm sabitleri, yapılar arasındaki kovaryanslar veya ölçme hataları en yüksek farka işaret eden değerden itibaren tek tek serbest bırakılmış ve modeller tekrar test edilmiştir. Böylelikle karşılaştırılan modelden anlamlı bir farklılığın olmadığına ilişkin elde edilen istatistikle test edilen model sınanmıştır. Sonuçta serbest bırakılan değerler ilgili istatistikte gruplar arasındaki farklılığg diğer değerler ise farksızlığ 1 göstermiştir.

Tablo 5: Çoklu Grup Karşılaştırmaları İçin Elde Edilen Uyum Değerleri (n=629)

\begin{tabular}{cccccccccc}
\hline Model & Ki kare $\left(\chi^{2}\right)$ & sd & $\chi^{2} / \mathbf{s d}$ & $\mathbf{p}$ & $\mathbf{C F I}$ & TLI & RMSEA & $\Delta$ TLI & $\Delta$ RMSEA \\
\hline Model 1 & 534.24 & 120 & 4.452 & .000 & .924 & .903 & .073 & - & - \\
Model 2 & 321.16 & 117 & 2.745 & .000 & .962 & .951 & .052 & - & - \\
Model 3 & 233.47 & 117 & 1.996 & .000 & .945 & .928 & .067 & - & - \\
Model 4 & 239.38 & 117 & 2.046 & .000 & .963 & .951 & .051 & - & - \\
Model 5 & 472.99 & 234 & 2.021 & .000 & .956 & .942 & .040 & - & - \\
Model 6 & 489.05 & 247 & 1.980 & .000 & .955 & .945 & .040 & $(-.003)$ & $(-.000)$ \\
& $(16.05)$ & $(13)$ & & $(.246)$ & & & & & \\
Model 7 & 514.19 & 264 & 1.948 & .000 & .954 & .947 & .039 & $(-.001)$ & $(-.002)$ \\
& $(41.195)$ & $(30)$ & & $(.084)$ & & & & & \\
Model 8 & 523.70 & 285 & 1.838 & .000 & .956 & .953 & .037 & $(-.000)$ & $(-.000)$ \\
& $(57.113)$ & $(51)$ & & $(.291)$ & & & & & \\
Model 9 & 545.65 & 293 & 1.862 & .000 & .953 & .951 & .037 & $(-.002)$ & $(-.000)$ \\
& $(72.657)$ & $(59)$ & $(.109)$ & & &
\end{tabular}

Parantez içindeki değerler serbest bırakılan değerler sonrasında ilgili model ile karşılaştırma istatistiklerini göstermektedir. CFI = Comparative Fit Index (Karşılaştırmalı uyum indeksi), TLI = Tucker Lewis Index (Tucker Lewis indeksi), RMSEA = Root Mean Square Error of Approximation (tahmin hatasının ortalama karakökü) 


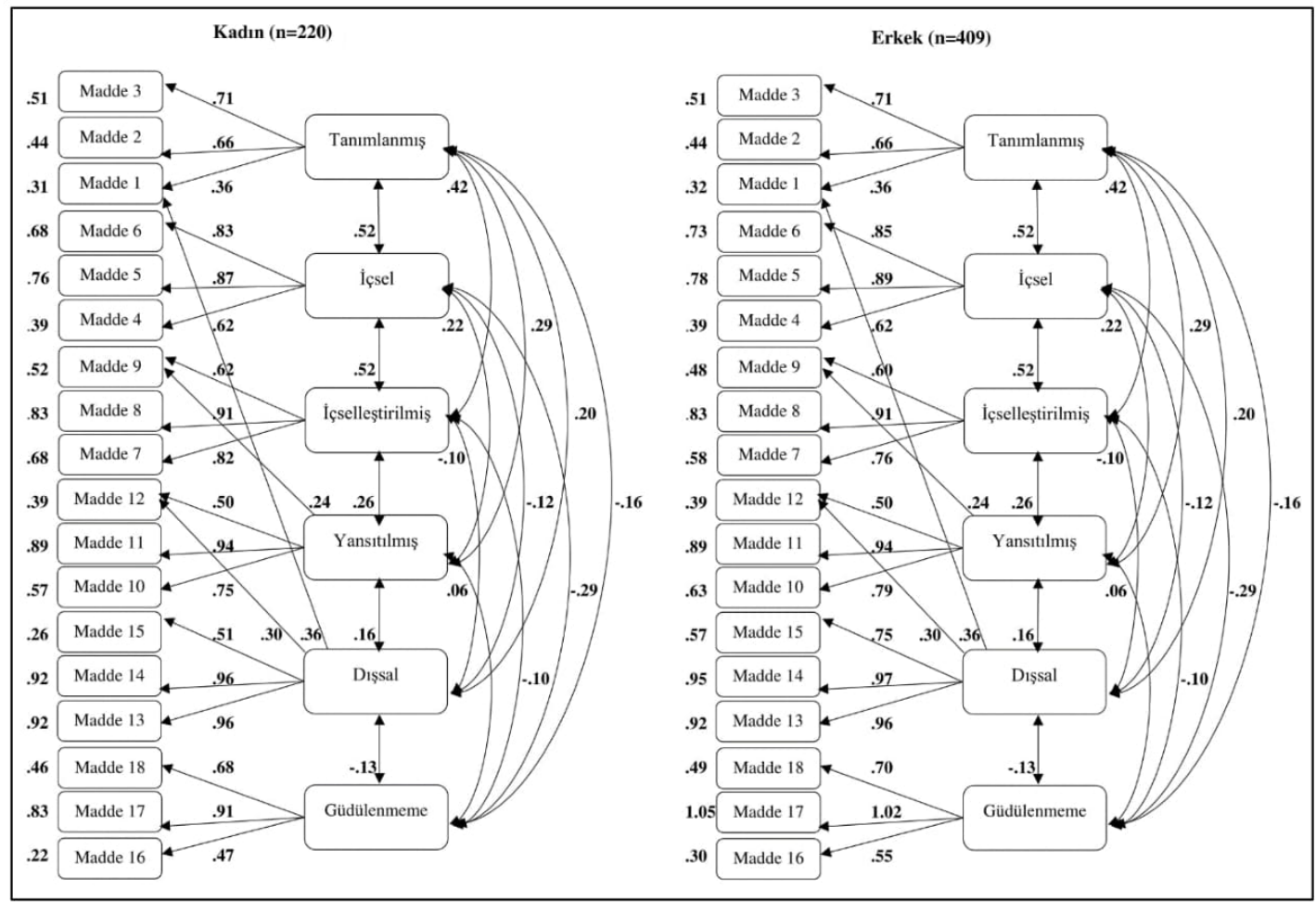

Şekil 3: İçsel ve Dışsal Güdülenme Ölçeğinin Cinsiyet Farksızlığına Ait 18 Maddelik Faktör Yapısı

Bu çerçevede Model 5 referans alınarak tüm faktör yükleri eşitlenerek model test edilmiş, elde edilen istatistik farklılığa işaret ettiğinden $(p<.000)$, en yüksek faktör yükü farklılığını gösteren iki faktörün $(31:$ Kadın $=.72, \mathrm{p}<.01$, Erkek $=.87, \mathrm{p}<.01$ ve 36 : Kadın $=.52, \mathrm{p}<.01$, Erkek $=.75, \mathrm{p}<.01)$ serbest bırakılması sonrasında modelin farksızlığı $(\mathrm{p}>$.246) elde edilmiştir (Model 6). Elde edilen bu model tüm ölçüm sabitleri eşitlenerek test edilmiş, önceki modelden anlamlı farklılık gösteren yeni modelde $(p<.000)$ bir gözlemlenen değişkenin ölçüm sabiti serbest bırakıldıktan sonra (37: Kadın $=2.267$, SD $=.06, \mathrm{p}<.01$, Erkek $=2.005, \mathrm{SD}=.07, \mathrm{p}<.01)$ modelin önceki modelden farksızlığ $(\mathrm{p}>$.084) belirlenmiştir (Model 7). Sonraki aşamada model yapıların varyansları ve aralarındaki kovaryanslar eşitlenerek test edilmiş ve önceki modelden farklılaşmadığı ( $\mathrm{p}>$.291) belirlenmiştir (Model 8). En son aşamada ölçüm hatalarının eşitlendiği modelin önceki modelden anlamlı biçimde farklılaştığı $(\mathrm{p}<.000)$, ancak 10 hata varyansının serbest birakılmasından sonra farklılığın olmadığ (p>.109) görülmüştür. Tüm bu analizler sonucunda, ölçeğin kadınlar ve erkekler açısından teorik olarak öne sürülen yapısının benzer olduğu, iki maddenin faktör yüklerinin erkekler için yüksek, bir maddenin ölçüm sabitinin ise kadınlar için yüksek olduğu ortaya çıkarılmıştır. Her ne kadar açıklanmayan hata varyanslarının yarısından çoğu eşit olmasa da ölçeğin yapısal ve ölçümsel olarak cinsiyet açısından farklılık oluşturmadığı sonucuna ulaşılmıştır.

\section{SONUÇ VE TARTIŞMA}

Bu çalışmada Tremblay ve arkadaşları (2009)'nın geliştirmiş olduğu içsel ve dişsal güdülenme ölçeğinin Türk kültürüne uyarlanması ve uygulanabilirliğinin test edilmesi amaçlanmıştır. $\mathrm{Bu}$ amaçla geçerlilik ve güvenilirlik analizleri iki farklı örneklemde (özel ve kamu sektörü) test edilmiştir. İlk olarak ölçeğin geçerliliğinin test edilmesi için her iki örneklemde yapı geçerliliğine bakılmıştır. Yap1 geçerliliği için yapılan doğrulayıcı faktör analiz sonucunda model uyum değerlerinin kabul edilebilir değerler içinde olduğu görülmüş ve ölçeğin altı boyutlu faktör yapısının iki örneklemde de doğrulandığı görülmüştür. Ayrıca ölçeğin benzeşim ve ayrışım geçerliliği de her iki örneklem için sağlanmıştır.

Ölçeğin ölçüt-bağımlı geçerliliğini test etmek amaciyla, rol performansı ve yaşam doyumu derecesini ölçen ölçeklerle ilişkileri iki örneklemde ayrı ayrı olarak incelenmiştir. Elde edilen anlamlı pozitif ve negatif ilişkiler alanyazın (Burton vd. 2006, Zhang, Zhang, Song, \& Gong, 2016) ile uygunluk göstermektedir. Bu bulgular, değişkenler arasında beklenen ilişkileri göstermekte ve ölçeğin bağımlı geçerliliğine yönelik kanıtlar sunmaktadır.

Ölçeğin güvenilirliği iki örneklemde ayrı ayrı test edilmiştir. Güvenilirlik analizi için, Cronbach Alfa değerine bakılmıştır. Birinci örneklemde 
güdülenmeme alt boyutu ve ikinci örneklemde tanımlanmış güdülenme alt boyutu hariç ulaşılan tüm tutarlılık değerleri yüksek çıkmıştır. Ölçeğin her iki örneklemde toplam Cronbach Alfa değerleri ise tutarlılık açısından iyi seviyelerdedir. Ölçeğin cinsiyet farksızlığının testi için iki örneklem verisi birleştirilerek altı boyutlu yapısı test edilmiş, kadın ve erkek açısından kısmı farklılıklar olmasına rağmen ölçeğin genel olarak farksızlığına ilişkin kanıtlara ulaşılmıştır.

Araştırmada elde edilen bulgular araştırmada kullannılan örneklem çerçevesinde sinırlılık taşımaktadır. Mevcut araştırma içsel ve dışsal güdülenme ölçeğinin güvenilir ve geçerli bir ölçüm aracı olarak kullanılması için yeterlil kanıtlar sunmaktadır. Ölçeği oluşturan altı boyutun, Öz Belirleme Teorisiyle açıklanması ölçeğin teorik gücünü ortaya koymaktadır. Bu nedenle gelecekte yapılacak araştırmalarda, güdülenmenin ölçülmesine yönelik alternatif güçlü bir ölçüm aracı olarak ölçeğin araştırmacılara sunulduğu değerlendirilmektedir. Ölçeğin farklı kültürlerde uygulanması, farklı değişkenlerle ilişkilerinin araştırılması ve farklı örneklem büyüklüğünde çalışılması sonucunda elde edilecek bulguların daha genellenebilir sonuçlara ulaştırabileceği değerlendirilmektedir.

\section{ETIKK BEYANATI}

Destek Bilgisi: Bu çalışma, kamu, ticari veya kâr amacı gütmeyen kuruluşlar gibi herhangi bir organizasyondan destek almamıştır.

Çıkar Çatışması: Tüm yazarlar adına, sorumlu yazar çıkar çatışması olmadığını belirtir.

Etik Onay: İnsan katılımcıları içeren çalışmalarda gerçekleştirilen tüm prosedürler, kurumsal ve / veya ulusal araştırma komitesinin etik standartlarına ve 1964 Helsinki deklarasyonuna ve daha sonraki değişikliklerine veya karşılaştırılabilir etik standartlara uygundur.

Bilgilendirilmiş Onam Formu: Çalışmaya katılan tüm bireysel katılımcılardan bilgilendirilmiş onam formu alınmıştır.

\section{KAYNAKÇA}

Amabile, T. M. (1993). Motivational synergy: Toward new conceptualizations of intrinsic and extrinsic motivation in the workplace. Human Resource Management Review, 3(3), 185-201.

Arshadia, N. (2010). Basic need satisfaction, work motivation, and job performance in an industrial company in Iran. Procedia - Social and Behavioral Sciences, $\quad 5, \quad 1267-1272$. https://doi.org/10.1016/j.sbspro.2010.07.273

Boiché, J. C. S., \& Sarrazin, P. (2007). Self-determination of contextual motivation, inter-context dynamics and adolescents' patterns of sport participation over time. Psychology of Sport and Exercise, 8(5), 685-703. https://doi.org/10.1016/j.psychsport.2006.10.004

Brislin, R. W. (1986). The Wording and translation of research instruments. In J. W. Lonner, W. J., \& Berry (Ed.), Field Methods in Cross-Cultural Research (pp. 137-164). SAGE Publications, Inc.

Burton, K. D., Lydon, J. E., D’Alessandro, D. U., \& Koestner, R. (2006). The differential effects of intrinsic and identified motivation on well-being and performance: Prospective, experimental, and implicit approaches to self-determination theory. Journal of Personality and Social Psychology, 91(4), 750-762. https://doi.org/10.1037/0022-3514.91.4.750

Çetin, A., Boyraz, M., \& Özer, S. (2019). Otel çalışanların iş motivasyonu ve çeşitli demografik değişkenlere göre farklılaşması: Denizli şehir otellerinde bir araştırma. Selçuk Üniversitesi Sosyal Bilimler Meslek Yüksekokulu Dergisi, 601-614. https://doi.org/10.29249/selcuksbmyd.589738

Çivilidağ, A., \& Şekercioğlu, G. (2017). Çok boyutlu iş motivasyonu ölçeğinin Türk kültürüne uyarlanması. Mediterranean Journal of Humanities, 7(1), 143-156. https://doi.org/10.13114/mjh.2017.326

Deci, E. L. (1972). The effects of contingent and noncontingent rewards and controls on intrinsic motivation. Organizational Behavior and Human Performance, 8(2), 217-229.

Deci, E. L., Olafsen, A. H., \& Ryan, R. M. (2017). Selfdetermination theory in work organizations: The state of a science. Annual Review of Organizational Psychology and Organizational Behavior, 4, 19-43.

Deci, E. L., \& Ryan, R. M. (1985). Intrinsic motivation and self-determination in human behavior. New York, NY: Plenum

Deci, E. L. \& Ryan, R. M. (2000). The "what" and the "why" of goal pursuits: Human needs and the selfdetermination of behavior. Psychological Inquiry, 11(4), 227-268. 
Ellemers, N., Gilder, D. De, \& Haslam, S. A. (2004). Motivating Individuals and groups at work: A Social 1dentity perspective on leadership and group performance. Academy of Management Review, 29(3), 459-478. https://doi.org/10.2307/20159054.

Fornell, C. \& Larcker, D. F. (1981). Evaluating structural equation models with unobservable variables and measurement error. Journal of Marketing Research, 18(1), 39-50.

Gagné, M., \& Deci, E. L. (2005). Self-Determination theory and work motivation. Journal of Organizational Behavior, 26(4), 331-362.

Gagné, M., Forest, J., Vansteenkiste, M., Crevier-Braud, L., van den Broeck, A., Aspeli, A. K., ... Westbye, C. (2015). The Multidimensional Work Motivation Scale: Validation evidence in seven languages and nine countries. European Journal of Work and Organizational Psychology, 24(2), 178-196. https://doi.org/10.1080/1359432X.2013.877892

Göncü Köse, A., \& Metin, U. B. (2019). Hangi lider, kurumda kalmayı nasıl sağlıyor? Çok boyutlu iş motivasyonunun aracı rolü. Türk Psikoloji Dergisi, 34(Özel Say1), 46-67. https://doi.org/10.31828/tpd1300443320190402x0000 31

Ingledew, D. K., Markland, D., \& Sheppard, K. E. (2004). Personality and self-determination of exercise behaviour. Personality and Individual Differences, 36(8), 1921-1932. https://doi.org/10.1016/j.paid.2003.08.021

Kanfer, R. (1990). Motivation Theory and industrial and organizational psychology. In M. D. Dunnette \& L. Hough (Eds.), Handbook of Industrial and Organizational Psychology (Vol.1) Theory in Industrial and Organizational Psychology (pp. 75170). Palo Alto: Cunsulting Psychologists Press.

Kara, A. (2008). İlköğretim birinci kademede eğitimde motivasyon ölçeğinin Türkçeye uyarlanması. Ege Ĕgitim Dergisi, 8(9), 59-78.

Köse, E. (2019). Çalışanların iş tatmini algıları ile iş motivasyonu düzeyleri arasındaki ilişkinin araştırılması. Bilecik Şeyh Edebali Üniversitesi Sosyal Bilimler Enstitüsü Dergisi, 4(1), 131-148. https://doi.org/10.33905/bseusbed.518499

Mitchell, T. R. (1982). Motivation: New Directions for theory, research, and practice. The Academy of Management Review, 7(1), 80-88. Retrieved from http://www.jstor.org/stable/257251

Nguyen, T. V. T., Weinstein, N., \& Ryan, R. M. (2021). The Possibilities of aloneness and solitude: Developing an understanding framed through the lens of human motivation and needs. the handbook of solitude: Psychological Perspectives on Social
Isolation, Social Withdrawal, and Being Alone, 224239.

Ryan, R. M., \& Deci, E. L. (2000a). Intrinsic and extrinsic motivations: Classic definitions and new directions. Contemporary Educational Psychology, 25(1), 54-67. https://doi.org/10.1006/ceps.1999.1020

Ryan, R. M., \& Deci, E. L. (2000b). Self-Determination theory and the facilitation of intrinsic motivation, social development, and well-being. The American Psychologist, 55(1), 68-78. https://doi.org/10.1037/0003-066X.55.1.68

Ryan, R. M. \& Deci, E. L. (2017). Self-determination theory: Basic psychological needs in motivation, development, and wellness. New York, NY: Guilford Publishing

Sigler, T. H., \& Pearson, C. M. (2000). Creating an empowering culture: Examining the Relationship between organizational culture and perceptions of empowerment. Journal of Quality Management, 5(1), 27-52. https://doi.org/10.1016/S10848568(00)00011-0

Stupnisky, R. H., BrckaLorenz, A., \& Laird, T. F. N. (2019). How does faculty research motivation type relate to success? A test of self-determination theory. International Journal of Educational Research, 98(8), 25-35. https://doi.org/10.1016/j.ijer.2019.08.007

Tremblay, M. A., Blanchard, C. M., Taylor, S., Pelletier, L. G., \& Villeneuve, M. (2009). Work extrinsic and intrinsic motivation scale: Its value for organizational psychology research. Canadian Journal of Behavioural Science, 41(4), 213-226. https://doi.org/10.1037/a0015167

Zhang, J., Zhang, Y., Song, Y., \& Gong, Z. (2016). The different relations of extrinsic, introjected, identified regulation and intrinsic motivation on employees' performance: Empirical studies following selfdetermination theory. Management Decision, 54(10), 2393-2412 


\section{Ek: İçsel ve Dışsal Güdülenme Ölçeği}

\section{İsini neden/niçin yaparsın?}

\section{Tanımlanmış Güdülenme}

Madde 1. Belirli bir yaşam biçimini (standardını) elde etmek amacıyla seçtiğim mesleğimin bir parçası olduğu için

Madde 2. Kendi kariyer amaçlarıma ulaşmak için bu mesleği seçtim

Madde 3. Önemli amaçlara ulaşmak amacıyla seçtiğim mesleğimin bir parçası olduğu için İcsel Güdülenme

Madde 4. Yeni şeyler öğrenmekten çok zevk aldığım için

Madde 5. Karşılaşı̆̆ı̆m ilgi çekici zorluklarla uğraşmaktan zevk aldığım için

Madde 6. Zorlu görevlerde başarılı olmaktan zevk aldığım için

İçselleştirilmiş Güdülenme

Madde 7. Kendi seçtiğim yaşam biçiminin bir parçası olduğu için

Madde 8. Benim yaşamımın bir parçası olduğu için

Madde 9. Benim kim olduğumun önemli bir parçasını oluşturduğu için

Yansıtılmış Güdülenme

Madde 10. Bu işte başarılı olmak isteğim için, aksi halde kendimden utanırdım

Madde 11. Bu işte çok iyi olmak istediğim için, aksi halde düş kırıklığı yaşardım

Madde 12. Yaşamda bir "kazanan" olmak istediğim için

Dışsal Güdülenme

Madde 13. Bana para kazandırdığ için

Madde 14. Bana sağladığı gelir/kazanç için

Madde 15. İş güvencesi/garantisi verdiği için

\section{Güdülenmeme}

Madde 16. Kendime bu soruyu hep sorarım. İșimde önemli görevler yaptığımı düşünmüyorum

Madde 17. Neden/niçin yaptığımı bilmiyorum, çok gerçekçi olmayan iş koşulları içindeyiz

Madde 18. Hiç bilmiyorum. Bizden çok şey istiyorlar. 